\title{
Toxicological Evaluation of Biological and Electrochemical Treatments of Coal Mine-impacted Water (MIW) on Duckweed Landoltia Punctata
}

\section{Caroline Rodrigues}

Universidade Federal de Santa Catarina https://orcid.org/0000-0002-2722-8588

Cristina M. Lalau

UFSC: Universidade Federal de Santa Catarina

\section{Dámaris Núñez-Gómez}

UFSC: Universidade Federal de Santa Catarina

\section{Rodrigo C. Puerari}

UFSC: Universidade Federal de Santa Catarina

\section{Hioná V. D. M. Follmann}

UFSC: Universidade Federal de Santa Catarina

\section{Bianca V. Oscar}

UFSC: Universidade Federal de Santa Catarina

Flávio R. Lapolli

UFSC: Universidade Federal de Santa Catarina

William Gerson Matias ( $\nabla$ william.g.matias@ufsc.br)

UFSC: Universidade Federal de Santa Catarina https://orcid.org/0000-0002-2386-0578

María Ángeles Lobo-Recio

UFSC: Universidade Federal de Santa Catarina

\section{Research Article}

Keywords: Acid mine drainage (AMD), mine-impacted water (MIW), electrocoagulation, biostimulation, duckweed, toxicity assay

Posted Date: February 7th, 2022

DOI: https://doi.org/10.21203/rs.3.rs-1232787/v1

License: (1) (1) This work is licensed under a Creative Commons Attribution 4.0 International License.

Read Full License 
4 Abbreviations: AMD: acid mine drainage; DF: dilution factor; DO: dissolved oxygen; elC:

5 electrocoagulation; $\mathrm{EC}_{50}$ : 50\% effect concentration; $I_{r}$ : inhibition rate; MAV: maximum allowable

6 value; MIW: mine-impacted water; $r$ : growth rate; SC: Santa Catarina state; SRB: sulfate-reducing 7 bacteria.

9 Keywords: Acid mine drainage (AMD); mine-impacted water (MIW); electrocoagulation; biostimulation, duckweed, toxicity assay.
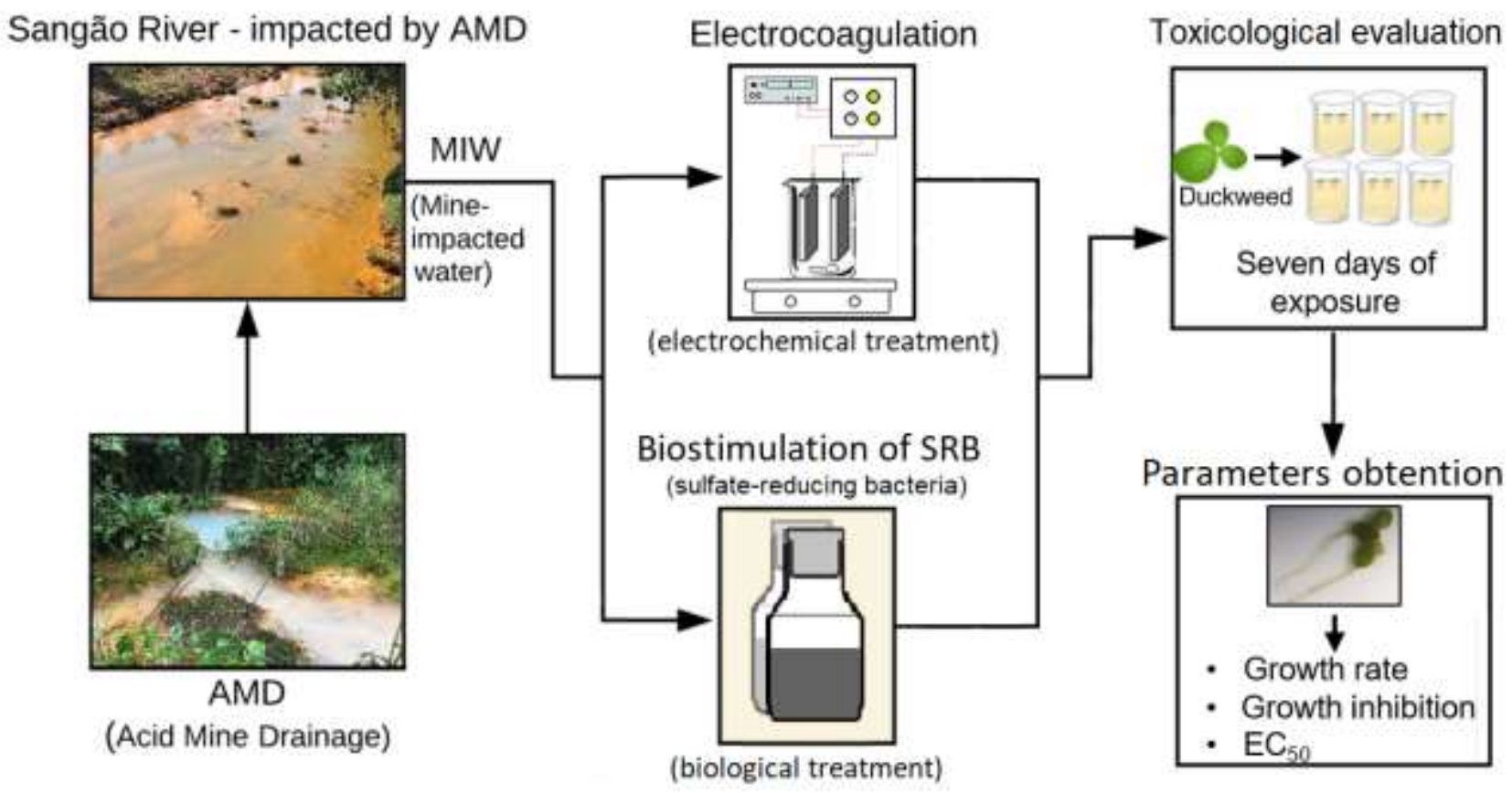

ABSTRACT

Two different coal mine-impacted water (MIW) treatments (biological via biostimulation of sulfatereducing bacteria $(\mathrm{SRB})$, and electrocoagulation (elC)) were proposed, reaching efficiencies of up to $99.79 \%$ in relation to $\mathrm{SO}_{4}{ }^{2-}, \mathrm{Fe}, \mathrm{Mn}$, and $\mathrm{Al}$ ions, as well as acidity removals. Thus, toxicological assays with duckweed Landoltia punctata were performed, in order to verify the safeness and usability of the two treated waters. Therefore, duckweeds were exposed to different dilutions $(0,25$, 50,75 , and $100 \%$ of samples) of the two treated waters, and the growth (r) and inhibition of growth $\left(I_{r}\right)$ rates were calculated, based on $50 \%$ effect concentration $\left(\mathrm{EC}_{50}\right)$. The water from the biological 
treatment (microcosm assay) presented the highest toxicity $\left(\mathrm{EC}_{50}=33.42 \%\right)$, even higher when compared to the raw MIW ( $\left.\mathrm{EC}_{50}=42.78 \%\right)$, probably due to the hydrogen sulfide, that even after a purge removal, remained in solution. The results showed that this water, despite being within the standards in physicochemical terms, demonstrated risks in terms of toxicity. The water from electrocoagulation (elC) treatment, in the opposite way, showed much less toxicity, even lower than the control, and therefore not reaching $\mathrm{EC}_{50}$, also suggesting a possible nutrient function of the treated water. Consequently, the treated water by elC could, for example, have a non-potable use. The study made it possible to prove the efficiency of elC treatment, the importance of post-treatment toxicological assessments, and the potential of the duckweeds as an option for a test organism in these types of evaluations.

\section{Introduction}

Mining operations can cause severe environmental impacts, because of acid mine drainage (AMD) formation and release. As an example in Brazil, the Carboniferous Basin of Santa Catarina (SC) State region is highly impacted (Núñez-Gómez et al. 2019; Rodrigues et al. 2019). The coal AMD formation results from pyrite oxidation, through several chemical and biological processes that generate an effluent which is highly acidic ( $\mathrm{pH} 2-3)$, with high sulfate $\left(\mathrm{SO}_{4}{ }^{2-}\right)$ and metallic ion (e.g., Fe, Al, Mn, Zn, Cu, etc.) concentrations (Sánchez-Andrea et al. 2014). This type of effluent, highly toxic and corrosive, continuously contaminates the surface and groundwater, creating water known as mine-impacted water (MIW) (Mamelkina et al. 2017).

The sulfate concentrations in coal MIW may range from hundreds to thousands of $\mathrm{mg} \cdot \mathrm{L}^{-1}$ (Nariyan et al. 2017), and previous studies (Rodrigues et al. 2019, 2020b) treated it successfully, yielding high removals of sulfate and metallic ions, as well as $\mathrm{pH}$ alkalization, by biostimulating sulfate-reducing bacteria (SRB), using shrimp shell waste as substrate. Electrocoagulation (elC) has also been tested, achieving sulfate removal efficiencies of up to $70.95 \%$, as well as $\mathrm{pH}$ neutralization (Rodrigues et al. 2020a).

The biota in aquatic environments with lower $\mathrm{pH}$ than its tolerance levels can die due to respiratory and osmoregulatory disorders, compromising the food chain (Netto et al. 2013). Thus, post-treatment toxicological assays are essential, since with them it is possible to identify the risks involving test-organisms to this exposure, such as physiological, morphological, and metabolic changes (Lalau et al. 2015). Additionally, these assays can ensure safe levels of exposure to the adverse and the harmful effects (Lee et al. 2018), that traditional physicochemical analysis cannot identify (Costa et al. 2008).

Plants are organisms that play a key role within the aquatic ecosystems as a food source, 
participating in the biogeochemical cycles through the production of oxygen and nutrients (Stegemeier et al. 2017). However, the exposure of these organisms to extreme environments, such as a high concentration of metallic ions and low $\mathrm{pH}$, can cause phytotoxicity and several other effects (Shanker et al. 2005; Tamás et al. 2006). Also, as plants belong to the basal level of the food chain, they can bioamplify the toxic effects to higher trophic levels (Martins 2014; Lalau et al. 2015).

Duckweed (Landoltia punctata) is a group of small floating macrophytes that grows in lentic freshwater environments, offering several advantages as bioindicators, including small size, direct absorption of contaminants by the leaves, rapid growth, and simple crop requirements (Lalau et al. 2020). These macrophytes have been successfully used in wastewater treatment and toxicity testing in recent years (Perreault et al. 2010, 2013; Zezulka et al. 2013; Lalau et al. 2015, 2020; Ziegler et al. 2016, 2019; Pereira et al. 2018). Also widely used to determine the impacts on an extensive range of substances released into the environment (Wang 1990), duckweed is being used in various international guidelines for ecotoxicological risk assessment (OECD 2006; ISO/DIS 20079 2010). Although these organisms are standardized as a toxicological model in several countries, assessments with their use are not yet standardized in Brazil (Lalau et al. 2015).

The purpose of this study was to evaluate the toxicology, through a 50\% effect concentration $\left(\mathrm{EC}_{50}\right)$ and growth rate, of the two MIW treatments proposed: electrochemical (through electrocoagulation) and biological (microcosm biostimulating SRB) treatment on the duckweed, since both proposed treatments provided high removals of sulfate and metallic ions. Thus, this treated effluent could possibly present potential for non-potable use (garden watering, washing sidewalks or crop irrigation), thereby reducing the demand for quality water for population supply.

\section{Materials and methods}

\subsection{Collection and characterization of mine-impacted water (MIW)}

The MIW used for this study was obtained from the Sangão River, located inside the carboniferous basin of the southern State of SC, Brazil (28 $\left.45^{\prime} 38.7^{\prime \prime} \mathrm{S} 49^{\circ} 25^{\prime} 58.1^{\prime \prime} \mathrm{W}\right)$. The samples were collected in non-sterile polypropylene bottles with no headspace, and kept at $4{ }^{\circ} \mathrm{C}$ until the start of the analyses (APHA 2017). They were filtered under vacuum using a $0.45-\mu \mathrm{m}$ pore membrane, and characterized (in terms of $\mathrm{pH}$, and $\mathrm{Fe}, \mathrm{Al}, \mathrm{Mn}, \mathrm{SO}_{4}{ }^{2-}$ ions) on the same day of the collection and after both treatments, at the Water Reuse Laboratory (LaRA), at UFSC. Table 1 shows the methodology used for each analysis. 
Table 1. Analytical methods used for characterization of samples

\begin{tabular}{cccc}
\hline Parameter & Method & Range & Equipment \\
\hline $\mathrm{Fe}$ & Ferrover $^{a}$ & $0.02-3.00 \mathrm{mg} \cdot \mathrm{L}^{-1}$ & \\
$\mathrm{Mn}$ & Periodate oxidation $^{a}$ & $0.1-20.0 \mathrm{mg} \cdot \mathrm{L}^{-1}$ & Spectrophotometer HACH \\
$\mathrm{Al}$ & Aluminum $^{a}$ & $0.008-0.800 \mathrm{mg} \cdot \mathrm{L}^{-1}$ & DR 5000 \\
$\mathrm{SO}_{4}{ }^{2-}$ & Sulfaver $^{a}$ & $2-70 \mathrm{mg} \cdot \mathrm{L}^{-1}$ & \\
$\mathrm{~S}^{2-b}$ & Methylene blue $^{a}$ & $5-800 \mu \mathrm{g} \cdot \mathrm{L}^{-1}$ & \\
$\mathrm{pH}$ & pHmeter lecture $^{c}$ & $1-14$ & $\mathrm{pHmeter} \mathrm{Thermo} \mathrm{Scientific}$ \\
$\mathrm{DO}^{c}$ & Oximeter lecture & - & Optical probe YSI ProODO \\
\hline
\end{tabular}

\subsection{SRB biostimulation setup and sulfide removal}

The biological treatment experiments were built up as performed by Rodrigues et al. (2020b) to biostimulate the SRB: microcosms glass flasks (500 mL of capacity) containing $260 \mathrm{~mL}$ of MIW together with $2.6 \mathrm{~g}$ of shrimp shell $\left(10 \mathrm{~g} \cdot \mathrm{L}^{-1}\right)$ as a carbon source. In preparation, the shrimp shell waste was washed, dried, and pulverized, as described by Núñez-Gómez et al. (2017). Before being added to the flasks, the MIW was submitted to a $\mathrm{N}_{2}$ purge, until it reached anoxia (DO $\leq 0.5 \mathrm{mg} \cdot \mathrm{L}^{-1}$, monitored with an oximeter reading), then it was added to the flasks with the aid of a peristaltic pump (to avoid oxygenation). The microcosms flasks were purged with $\mathrm{N}_{2}$ before and after the MIW was inserted, sealed with a silicone stopper, kept in a dark room at $20 \pm 1{ }^{\circ} \mathrm{C}$ (controlled with a wall thermometer) for 41 days of incubation, being shaken manually once a day (to ensure homogeneity of the flask contents).

As a result of the sulfate reduction by the SRB, the hydrogen sulfide $\left(\mathrm{H}_{2} \mathrm{~S}\right)$ started to accumulate, and to remove it as gas, at the end of the microcosm period of incubation, an $\mathrm{N}_{2}$ purge system was assembled. The $\mathrm{H}_{2} \mathrm{~S}$ is a weak diprotic acid, and its form depends directly on the $\mathrm{pH}\left(\mathrm{H}_{2} \mathrm{~S}\right.$, $\mathrm{HS}^{-}$, and $\mathrm{S}^{2-}$ ), its neutral form being partially soluble in water and toxic gas. Inside a fume hood, the flasks were purged with $\mathrm{N}_{2}$, and the outgoing gas flow $\left(\mathrm{H}_{2} \mathrm{~S}+\mathrm{N}_{2}\right)$ was bubbled into a $\mathrm{NaOH}$ solution, generating sodium sulfide (Eq. 1), thus avoiding leakage of the toxic gas to the outside. Each flask was purged for 30 minutes (four flasks per time, with a four-way manifold splitter, Fig. 1). After this sulfide removal process, the microcosms contents were filtered (also inside a fume hood), characterized, and submitted to toxicological assay.

$$
\mathrm{H}_{2} \mathrm{~S}_{(g)}+2 \mathrm{NaOH}_{(a q)} \rightarrow \mathrm{Na}_{2} \mathrm{~S}_{(a q)}+2 \mathrm{H}_{2} \mathrm{O}
$$


(A)

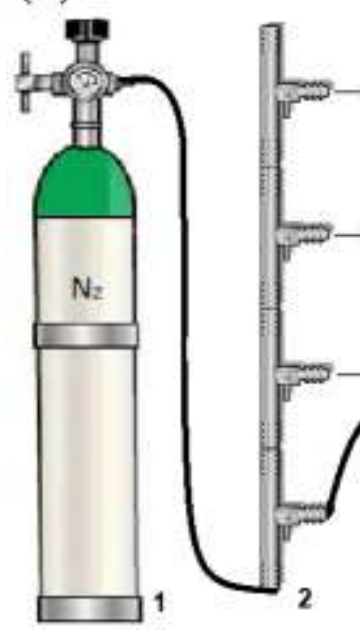

(B)

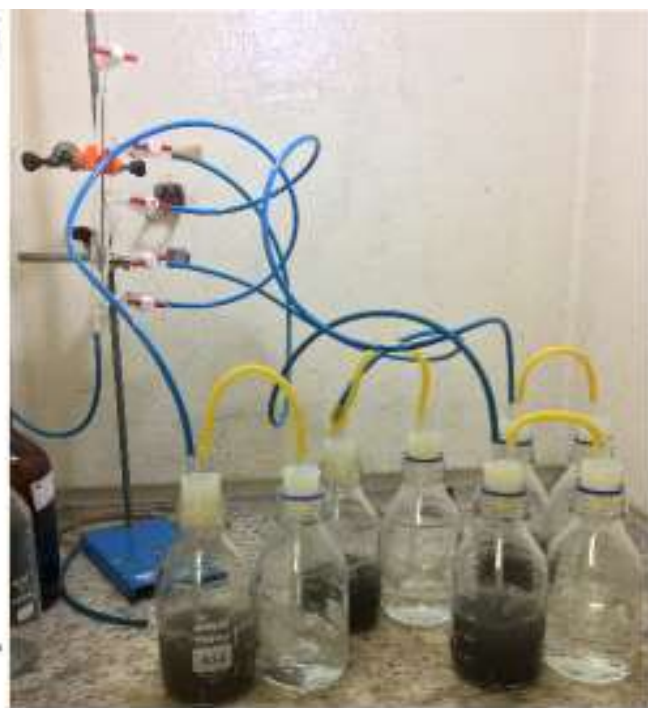

Fig. 1 (A) Scheme and (B) picture for the hydrogen sulfide removal apparatus: (1) Nitrogen cylinder; (2) four-way manifold gas line splitter; (3) Microcosm flask after 41 days incubation; (4) $\mathrm{NaOH}$ solution flask. The manifold splitter allowed to purge four microcosms per time.

\subsection{Electrocoagulation (elC) assay for MIW treatment}

An electrochemical system to treat MIW was carried out in bench-scale, as performed previously (Rodrigues et al. 2020a). The system consisted of duplicates of reactors (1-L plastic beaker), in which flat plate electrodes of $\mathrm{Al}$ (anode) and stainless steel (cathode) were immersed, spaced $5 \mathrm{~cm}$ from each other. The electrodes had the following dimension: $5.65 \times 13.9 \mathrm{~cm}$, with a useful area of $28.76 \mathrm{~cm}^{2}$ (anode). Magnetic stirrers were used during the process to homogenize, since a chemical species concentration gradient naturally occurs. A control panel regulated the electric current from the power supply (PS-A305D), providing a $65 \mathrm{~A} \cdot \mathrm{m}^{-2}$ current density, in continuous mode of exposure (of electric current) that goes into each elC reactor (Fig. 2). In this batch assay, $1 \mathrm{~L}$ of MIW was inserted in each beaker, the room temperature was controlled and kept at $23 \pm 1{ }^{\circ} \mathrm{C}$, and the total electric current time was 5 hours. After this period, the content was filtered for characterization, and submitted to toxicological assay. 

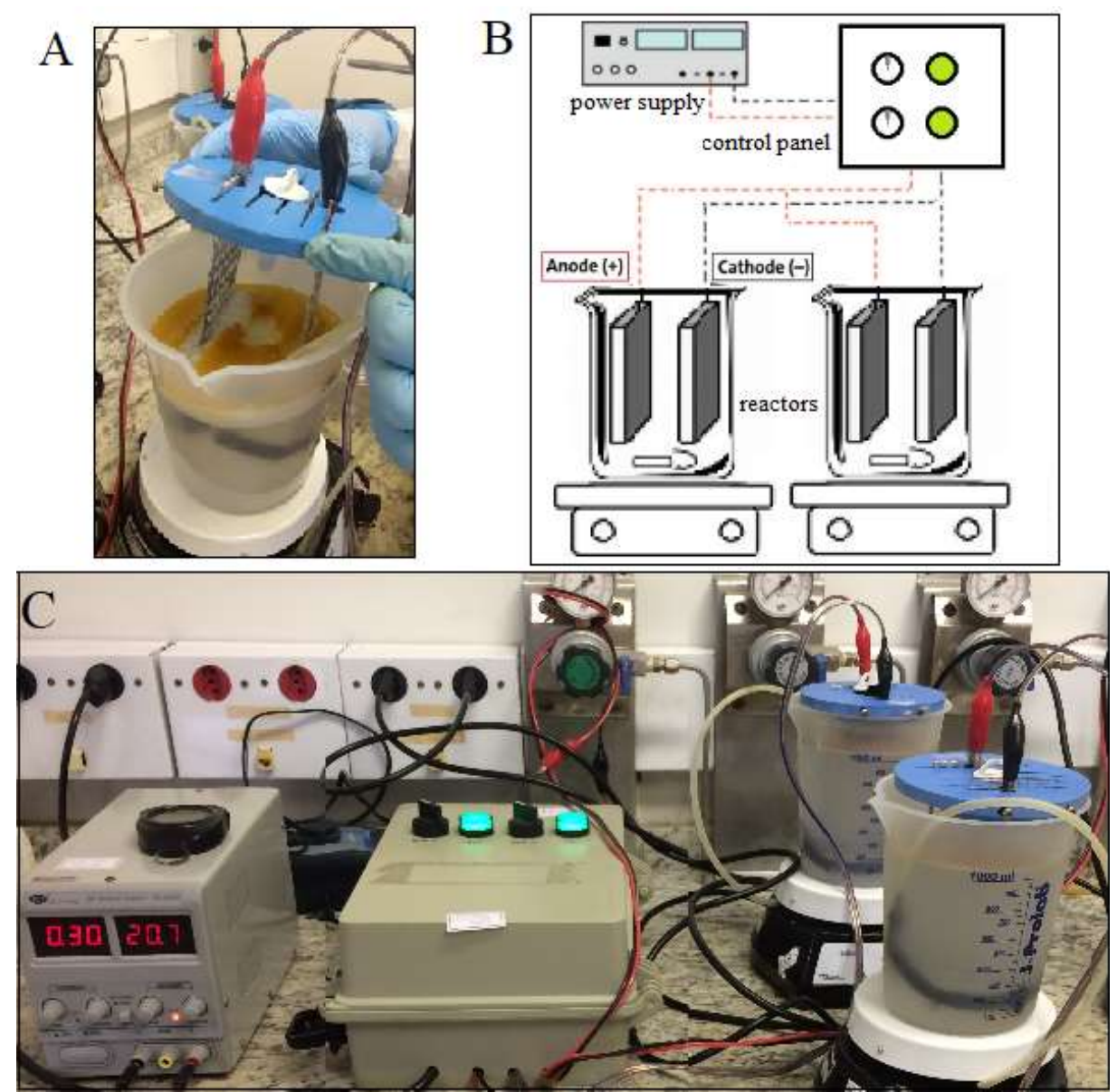

Fig. 2 (A) elC reactor profile along with its immersed electrodes (red anode and black cathode); (B) An illustrative scheme (C) Photograph of the elC bench apparatus. Adapted from (Rodrigues et al. 2020a).

\subsection{Toxicological assay}

The toxicological tests were carried out at the Laboratory of Environmental Toxicology (LABTOX), at UFSC. The duckweeds were collected from the natural environment and adapted to laboratory conditions according to international standards (OECD 2006; ISO/DIS 20079 2010). The inoculation procedure of the plant and culture medium were elaborated according to international standards (OECD 2006; ISO/DIS 20079 2010), and as described by Lalau et al. (2015, 2020). The culture medium composition was: $\mathrm{MgSO}_{4} .7 \mathrm{H}_{2} \mathrm{O}\left(15 \mathrm{~g} \cdot \mathrm{L}^{-1}\right), \mathrm{NaNO}_{3}\left(8.5 \mathrm{~g} \cdot \mathrm{L}^{-1}\right), \mathrm{Na}_{2} \mathrm{CO}_{3}\left(4 \mathrm{~g} \cdot \mathrm{L}^{-1}\right)$, $\mathrm{CaCl}_{2} \cdot 2 \mathrm{H}_{2} \mathrm{O}\left(7.2 \mathrm{~g} \cdot \mathrm{L}^{-1}\right), \mathrm{KH}_{2} \mathrm{PO}_{3}\left(1.34 \mathrm{~g} \cdot \mathrm{L}^{-1}\right), \mathrm{H}_{3} \mathrm{BO}_{3}\left(1 \mathrm{~g} \cdot \mathrm{L}^{-1}\right), \mathrm{MnCl}_{2} \cdot 4 \mathrm{H}_{2} \mathrm{O} \quad\left(0.2 \mathrm{~g} \cdot \mathrm{L}^{-1}\right)$, $\mathrm{Na}_{2} \mathrm{MoO}_{4} .2 \mathrm{H}_{2} \mathrm{O}\left(0.01 \mathrm{~g} \cdot \mathrm{L}^{-1}\right), \mathrm{ZnSO}_{4} .7 \mathrm{H}_{2} \mathrm{O}\left(0.05 \mathrm{~g} \cdot \mathrm{L}^{-1}\right), \mathrm{CuSO}_{4} .5 \mathrm{H}_{2} \mathrm{O}\left(0.005 \mathrm{~g} \cdot \mathrm{L}^{-1}\right), \mathrm{Co}\left(\mathrm{NO}_{3}\right)_{2} .6 \mathrm{H}_{2} \mathrm{O}$ $\left(0.01 \mathrm{~g} \cdot \mathrm{L}^{-1}\right), \mathrm{Na}_{2} \operatorname{EDTA}\left(0.28 \mathrm{~g} \cdot \mathrm{L}^{-1}\right)$, and $\mathrm{FeCl}_{3} \cdot 6 \mathrm{H}_{2} \mathrm{O}\left(0.168 \mathrm{~g} \cdot \mathrm{L}^{-1}\right)$.

Four different assays were performed for comparative purposes: MIW after biostimulation, MIW after electrocoagulation, raw MIW, and raw MIW with corrected $\mathrm{pH}$ (with $\mathrm{NaOH}$ solution until $\mathrm{pH}=7$ ). The latter assay was included because the MIW $\mathrm{pH}$ is acid, and duckweed needs a $\mathrm{pH}$ between $5-9$. 
The MIW samples were diluted with culture medium, and for the analysis of toxic effects, dilution factor (DF) was used, being 0\% (control - only culture medium), 25\% (1:4, i.e., 1 part of crude sample diluted in 3 parts of culture medium), 50\% (1:2), 75\% (1:1.333), and 100\% (gross sample-1:1) (Iatrou et al. 2015), as detailed in Table 2, with a total of six replicates for each dilution. The total volume was $100 \mathrm{~mL}$ in all cases.

Table 2. Different dilutions applied in Landoltia punctata for the growth rate experiments.

\begin{tabular}{lcccc}
\hline & $\begin{array}{c}\text { MIW parts:total parts } \\
(\mathbf{v} / \mathbf{v})\end{array}$ & $\begin{array}{c}\text { DF } \\
(\boldsymbol{\%})\end{array}$ & $\begin{array}{c}\text { MIW volume } \\
(\mathbf{m L})\end{array}$ & $\begin{array}{c}\text { Medium volume } \\
(\mathbf{m L})\end{array}$ \\
\hline Control & $0: 1$ & 0 & 0 & 100 \\
& $1: 4$ & 25 & 25 & 75 \\
& $1: 2$ & 50 & 50 & 50 \\
Gross sample & $1: 1.333$ & 75 & 75 & 25 \\
& $1: 1$ & 100 & 100 & 0 \\
\hline
\end{tabular}

163

All experiments were conducted in 100 mL-beakers, and each one was inoculated with duckweed and incubated in a temperature-controlled incubator $\left(25 \pm 2{ }^{\circ} \mathrm{C}\right)$ under an $18 \mathrm{~h}$-continuous illumination with fluorescent lamps (photoperiod). The $\mathrm{pH}$ was adjusted to the range of 6.5 to 7 , using $\mathrm{HCl}$ or $\mathrm{NaOH}$, except for raw MIW. The test started $\left(t_{0}\right)$ with a total of ten healthy fronds $\left(F N_{0}\right)$ for each dilution and lasted seven days. At the end of the test $\left(t_{1}\right)$ the frond number $\left(F N_{1}\right)$ was counted and the growth rate $(r)$ was calculated according to Eq. 2. The inhibition rate $\left(I_{r}\right)$ of the specific growth rate (\%) was calculated according to Eq. 3 (OECD 2006; ISO/DIS 20079 2010):

$$
\begin{aligned}
& r=\frac{\ln \left(F N_{1}\right)-\ln \left(F N_{0}\right)}{t_{1}-t_{0}} \\
& I_{r}=\frac{r_{c}-r_{t}}{r_{c}} x 100
\end{aligned}
$$

Where $r_{c}$ is the average specific growth rate of the control, and $r_{t}$ the average specific treatment growth rate to each DF tested. For the $\mathrm{EC}_{50}$ determination, the $I_{r}$ values were plotted against DF, and the regression of this concentration-response curve was performed. $\mathrm{EC}_{50}$ is defined as the sample concentration where $50 \%$ of effect is observed, when compared to the control. In this case, the effect is the growth inhibition $\left(I_{r}\right)$.

The values of the parameters (growth rate and growth inhibition) were calculated through mean and standard deviations. The significant differences between the means of treatments and control samples were obtained from analysis of variance according to the Tukey test, and performed through Statistica (v.10, 2011) software. 


\section{Results and discussion}

\subsection{MIW characterization and treatments}

In the biological treatment (SRB biostimulation), where there was sulfate reduction activity, sulfate and acidity were removed, as well as metallic ions (Fe, Al, and $\mathrm{Mn}$ ). Similarly, for the elC treatment, the same parameters were also removed, and Table 3 shows those values from MIW before and after treatments, as well as Brazilian guidelines for comparison. The maximum allowable values (MAV) were based on Resolution CONAMA 357/2005 (Brazil 2005), which provides parameters for secondary non-potable reuse. Resolution CONAMA 430/2011 (Brazil 2011), environmental legislation for effluent releases, was evidenced as a complimentary guideline.

Table 3. Physicochemical characterization of MIW for SRB biostimulation and elC treatments.

\begin{tabular}{|c|c|c|c|c|c|c|}
\hline & Treatm. & pH & $\begin{array}{c}\mathrm{SO}_{4}{ }^{2-} \\
\left(\mathrm{mg} \cdot \mathrm{L}^{-1}\right)\end{array}$ & $\begin{array}{c}\text { Fe } \\
\left(\mathrm{mg} \cdot \mathrm{L}^{-1}\right)\end{array}$ & $\begin{array}{c}\text { Mn } \\
\left(\mathrm{mg} \cdot \mathrm{L}^{-1}\right)\end{array}$ & $\begin{array}{c}\text { Al } \\
\left(\mathrm{mg} \cdot \mathrm{L}^{-1}\right)\end{array}$ \\
\hline Before treatment & \multirow{3}{*}{$\begin{array}{c}\text { SRB } \\
\text { biostimulation }\end{array}$} & 3.20 & 180 & 8.40 & 1.60 & 5.00 \\
\hline After treatment & & 7.19 & 2.00 & 0.31 & 0.10 & 0.14 \\
\hline Removal efficiency & & - & $98.89 \%$ & $96.31 \%$ & $93.75 \%$ & $97.20 \%$ \\
\hline Before treatment & \multirow{3}{*}{$\mathrm{elC}$} & 3.84 & 300 & 29.2 & 2.0 & 10.84 \\
\hline After treatment & & 8.94 & 84 & 0.06 & 0.30 & 1.37 \\
\hline Removal efficiency & & - & $72.00 \%$ & $99.79 \%$ & $85.00 \%$ & $87.36 \%$ \\
\hline 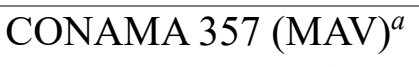 & \multirow{2}{*}{ Legislation } & $6-9$ & 250 & 5 & 0.5 & 0.2 \\
\hline CONAMA $430^{b}$ & & $5-9$ & - & 15 & 1.0 & - \\
\hline
\end{tabular}

195

196

197

198

${ }^{a}$ Maximum allowable values for Class III water, adequate for non-potable reuse (Brazil 2005).

${ }^{b}$ Brazilian conditions and standards of effluent releases (Brazil 2011).

For the biological treatment, although sulfate was already in line with the MAV, it presented a $98.89 \%$ removal, restating the efficiency of this process. The metallic ions also presented a $93.75 \%$ or greater removal, and reached the MAV, at the end of 41 days of treatment. The $\mathrm{pH}$ increased considerably, reaching neutrality due to the natural presence of carbonates in the shrimp shell. It is likely the alkaline $\mathrm{pH}$ helped in the removal process of metallic ions, or it was precipitation in the form of hydroxides $\left(\mathrm{OH}^{-}\right)$, bicarbonates $\left(\mathrm{HCO}_{3}{ }^{-}\right)$, carbonates $\left(\mathrm{CO}_{3}{ }^{2-}\right)$, and sulfides $\left(\mathrm{S}^{2-}\right)$.

For the elC treatment, equally reasonable efficiencies were reached, besides a much more alkaline $\mathrm{pH}$ and a 5 hour treatment length. The sulfate, that was removed via several aluminum sulfate complexes (Rodrigues et al. 2020a), presented a 72\% removal efficiency, but this was still within the MAV. The metallic ions yielded efficiencies between $85 \%$ and $99.79 \%$, and except for Al, they were in line with the MAV. For Al, even though it can be precipitated in a pH equal or higher than 6 (Falagán et al. 2017), in a pH near 9 it may re-solubilize as an aluminate ion $\left(\mathrm{Al}(\mathrm{OH})_{4}^{-}\right)(\mathrm{Kaur}$ et al. 2018), likely being the reason that its concentration was almost seven times above the MAV (Table 
3). It is worth mentioning that the aluminum is released continuously by the anode as a coagulant agent. In this assay, for operation in a non-reducing atmosphere (differently from the microcosms assay), no sulfide was formed, thus, the precipitation is caused by hydroxides, (bi)carbonates, and complexed sulfates (Rodrigues et al. 2020a).

Subsequently, the MIW from microcosm and elC treatments were submitted to toxicological assay, in order to ensure safeness and quality of the treated effluent.

\subsection{Toxicological assay for growth and inhibition rate}

Fig. 3 exposes the growth rates of duckweed for the four experiments carried out: effluents from both treatments (biological and elC), raw MIW, and corrected $\mathrm{pH}$ MIW. From these results it is possible to observe that the MIW after biostimulation (Fig. 3A), raw MIW (Fig. 3C), and corrected pH MIW (Fig. 3D) presented the same pattern: significant different (and lower) growth rates compared to the control (0 DF), evidencing therefore, that they have considerable toxicity, since growth decreased as the concentration (DF) increased. For specific cases of SBR biostimulation, the growth is zero from $50 \%$ of DF. The differences in the growth rate for the four controls are attributed to small differences in the medium composition, as the four experiments were carried out on different days with freshly prepared solutions.
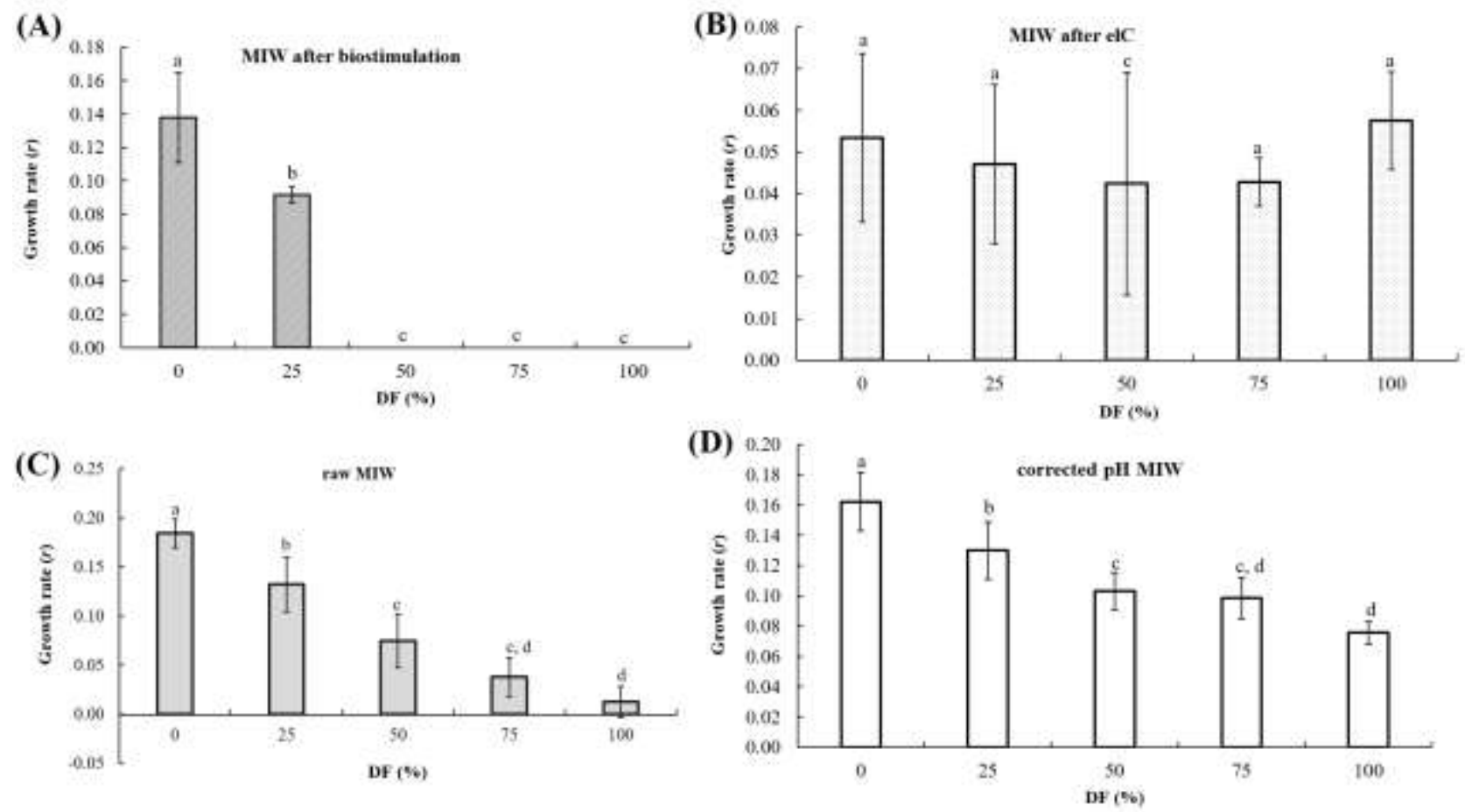

Fig. 3 Growth rate of Landoltia punctata after 7 days exposed to different effluents and dilution percentages: (A) MIW after biostimulation treatment, (B) MIW elC treatment, (C) raw MIW and (D) corrected $\mathrm{pH}$ MIW. Letters indicate significant differences according to one-way ANOVA and posterior Tukey test $(p \leq 0.05)$. The data points represent the average values and the error bars represent the standard deviation. 
Otherwise, in relation to the elC treatment results (Fig. 3B), for all concentrations (except for the $50 \%$ DF), they presented no significant difference from the control, as shown by the same letter "a" from the ANOVA study (Fig. 3B), therefore low toxicity and good quality of this effluent is inferred. It is important to note a slight increase in growth rate for the elC effluent in the $100 \% \mathrm{DF}$ (gross sample). The hypothesis that this sample has some element that may have stimulated the growth of duckweed is raised. The ability of an $\mathrm{Mn}$ ion to act like a micronutrient when in adequate concentrations, stimulating the chlorophyll formation, and intervening in the production of enzymes is well known. Enzymes play an important role in protein metabolism and cellular division (Chatzistathis et al. 2011; Soiltech 2021).

In relation to the inhibition of growth rate, most of the results (Fig. 4A, C and D) showed the same toxicological trend: as the DF increased, the inhibition also increased, especially for the SRB biostimulation treatment (Fig. 4A), which increased at a higher rate than the other samples.
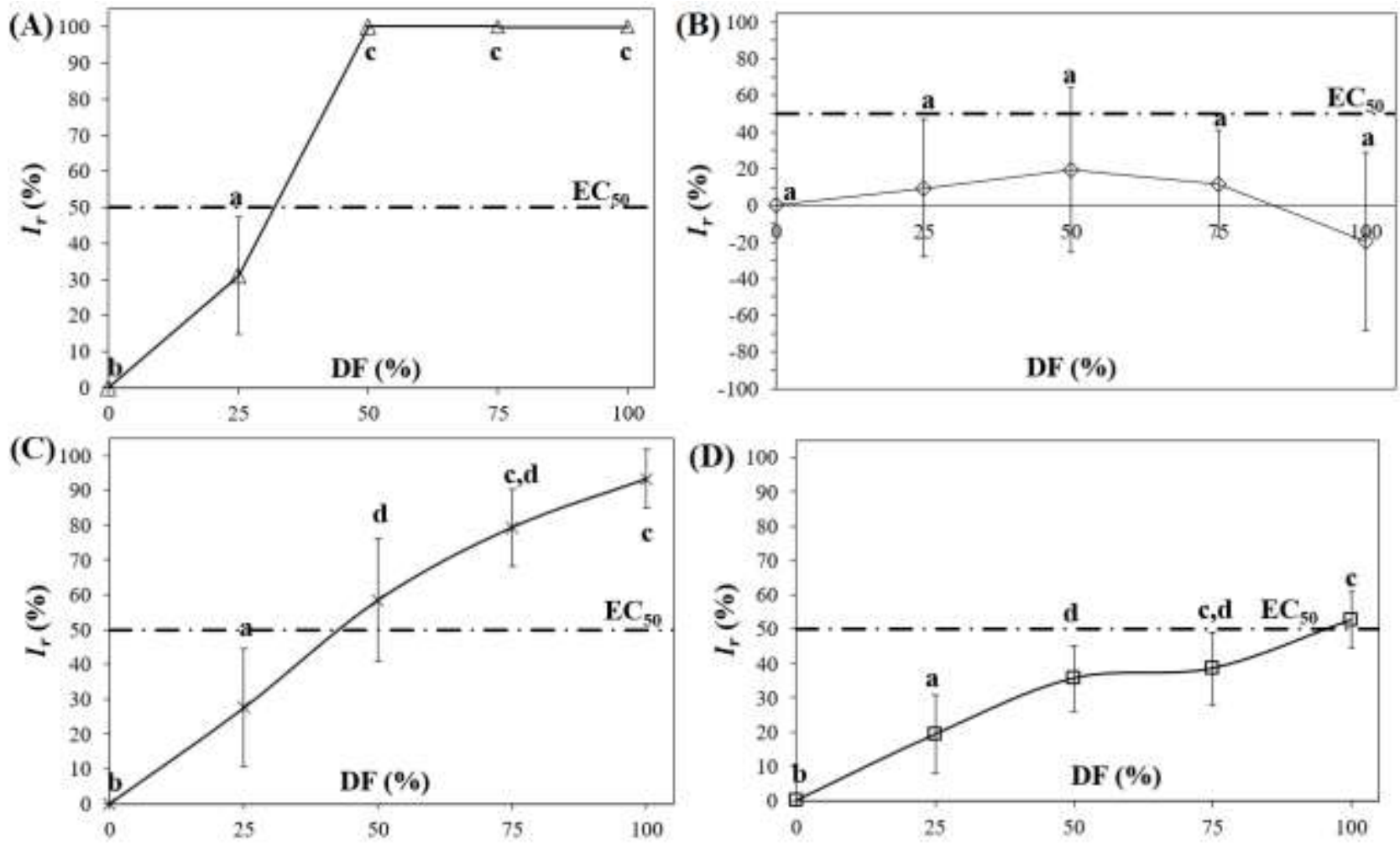

Fig. 4 Response curve after 7-days exposure: the results were based on the \% inhibition rate $\left(I_{r}\right)$ versus dilution factor (DF) to (A) SRB biostimulation treatment, (B) elC treatment, (C) raw MIW and (D) corrected $\mathrm{pH}$ MIW. Letters indicate significant differences according to one-way ANOVA and posterior Tukey test $(p \leq 0.05)$. The data points represent the average values and the error bars represent the standard deviation.

The raw MIW (Fig. 4C) also presented considerable toxicity as the concentration increased, with significant difference between the inhibition rates at the different DF. In the case of corrected pH MIW (Fig. 4D), its inhibition rate was also raised at a higher DF, but in a smoother way. Between 
these two last treatment results (raw MIW and corrected $\mathrm{pH}$ MIW), the effect of a simple $\mathrm{pH}$ correction (to 7) in toxicity is highlighted, revealed by their $\mathrm{EC}_{50}$ value $(42.78 \%$ and $92.37 \%$ of DF, Table 4). This is coherent with the ideal conditions for duckweed development (minimum pH of 6.5) (OECD 2006; ISO/DIS 20079 2010). The main factor associated with toxicity was evidenced by $\mathrm{pH}$ correction. This fact was already expected, as coal mines in the region impact water resources.

Table 4. $\mathrm{DF}$ values for each test reach the $\mathrm{EC}_{50}$, listed in descending order of toxicity.

\begin{tabular}{ccc}
\hline Type of treatment & DF (\%) for EC50 & Toxicity level \\
\hline SRB biostimulation & 33.42 & A more toxic \\
Raw MIW & 42.78 & \\
Corrected pH MIW & 92.37 & less toxic \\
elC & - & atoxic \\
\hline
\end{tabular}

In addition, it should be taken into account that in acid medium there are also potentially dissolved metallic ions. Studies (Chamorro et al. 2018) state that the metallic ions in AMD are largely responsible for its toxicity, and Lattuada et al. (2009) reach the same conclusion.The toxicity of raw MIW is corroborated by an analogous study (Nagy et al. 2020), that also observed toxic effects in duckweed (Lemna minor) when exposed to AMD.

In the opposite way, for the elC toxicological experiment (Fig. 4B), no statistical differences were observed in the inhibition of growth rates with increasing DF, even presenting a slightly negative inhibition of growth rate for the gross sample (100\% of DF), corroborating the earlier graph (Fig. 3). As it did not reach a $50 \%$ inhibition rate, it was not possible to determine the $50 \%$ effect concentration $\left(\mathrm{EC}_{50}\right)$. This type of result is in agreement with that found in the literature: Radic et al. (2014) also obtained a decrease in the toxicity when evaluating AMD treatment using a combined $\mathrm{CaO} / \mathrm{elC}$ process, using the organisms Daphnia magna and Lemna minor.

In the present study, since a slight stimulus in the growth of plants exposed to the effluent from the elC treatment was observed, a sufficient removal of metal ions ceasing to be toxic and behaviour like nutrients can be inferred. As macrophytes need nutrients for their development (Teles et al. 2017), the results suggest that the treated effluent may have a nutrient function for the duckweed.

The SRB biostimulation treatment showed toxicity in Landoltia punctata, reaching 100\% inhibition with only 50\% of DF (Fig. 4A) and the lowest EC50 value (33.42 of DF, Table 4) in spite of the neutral $\mathrm{pH}$. The highest toxicity from SRB biostimulation treatment is probably due to the presence of residual sulfide, which even after the purge removal process, still showed a $200 \mu \mathrm{g} \cdot \mathrm{L}^{-1}$ concentration. This residual concentration can be explained by $p k a_{1}$, which is shown by Eq. 4 (Atkins et al. 2018): 


$$
\begin{gathered}
H_{2} S_{(a q)} \rightleftharpoons H^{+}{ }_{(a q)}+H S^{-}{ }_{(a q)}\left(p k a_{1}=6.9\right) \\
H_{2} S_{(a q)} \rightleftharpoons H_{2} S_{(g)}
\end{gathered}
$$

Due to the $\mathrm{pH}$ of the microcosm (7.19) being close to the $p k a_{1}(6.9)$, the $\mathrm{H}_{2} S_{(a q)}$ remained partly in solution in equilibrium with $\mathrm{H}^{+}{ }_{(\mathrm{aq})}+\mathrm{HS}^{-}$(aq) (Eq. 4), making its escape to the gaseous phase difficult (Eq. 5) even with the use of $\mathrm{N}_{2}$ as a purge gas.

Conventional treatment using electrocoagulation proved to be efficient in reducing toxicity, and the treatment performed by biostimulation, under the conditions of the experiment, proved to be ineffective. However, the correction of MIW pH proved to be efficient in reducing toxicity. Despite the low efficiency of biostimulation, the results show that it presents a good opportunity for studies and that further research can be carried out to improve the method.

Duckweed species are sensitive to extreme environments (Wang 1990), and the results obtained in the present study demonstrate this, probably due to the presence of hydrogen sulfide, known to be toxic even to human beings (APHA 2017). It should also be noted that the odor resulting from this treated effluent is very pungent, detracting therefore from a non-potable secondary reuse application, since it would be impracticable to use it (for example, for garden irrigation, sidewalk washing, etc).

\section{Conclusions}

According to the toxicological evaluation performed, among the proposed MIW treatments, the BRS biostimulation (microcosm) and the elC, the latter evidenced no toxicity, even presenting nutrient potential for duckweed. However, the effluent from biological treatment, which in physicochemical terms showed even greater removal of sulfate and metallic ions, presented high toxicity, even higher than raw MIW. This is probably due to the residual hydrogen sulfide that remained, even after purging, because of the $\mathrm{pH}$. In this sense, the quality of MIW treated in the elC assay was superior to the assay treated by biostimulation. This supported the fact that the elC treated effluent does not present odor and requires treatment of only a few hours, showing its potential for non-potable use purposes, conferring a use for a water initially highly polluted, for instance for irrigation, due to its suggested nutrient function. The findings also led to the conclusion that despite the physicochemical parameters of the effluent from biological treatment having met the requirements of the legislation for the evaluated parameters, the effluent does not meet the toxicity standards, which reveals the importance of these assessments. In addition, the macrophytes proved to be an interesting organism in these types of evaluations.

Furthermore, in future tests, scanning electron microscopy (SEM) and transmission electron 
microscopy (TEM) images from the duckweed organelles tissues will be carried out, in order to visualize possible damage from the exposure, and complement the toxicological evaluation, providing more information about the mechanism of the toxicity observed.

Conflict of interest: The authors declare that they have no conflict of interest.

\section{Declarations}

329 Consent to participate: Not applicable.

330 Consent to publish: Not applicable.

Availability of data and materials: Not applicable.

\section{References}

APHA (2017) Standard Methods for the Examination of Water and Wastewater, 23rd edn. American

Public Health Association, American Water Works Association, Water Environment Federation, Washington D.C.

Atkins P, Jones L, Laverman L (2018) Princípios de química: questionando a vida moderna e o meio ambiente, 7a. Bookman, Porto Alegre

Brazil (2005) National Council of the Environment (CONAMA). Resolut. no 357 58-63

Brazil (2011) National Council of the Environment (CONAMA). Resolut. no 430 1-9

Chamorro S, Barata C, Piña B, et al (2018) Toxicological analysis of acid mine drainage by water quality and land use bioassays. Mine Water Environ 37:88-97. https://doi.org/10.1007/s10230$\underline{017-0472-2}$

Chatzistathis TA, Papadakis IE, Therios IN, et al (2011) Is chlorophyll fluorescence technique a useful tool to assess manganese deficiency and toxicity stress in olive plants? J Plant Nutr 34:98-114. https://doi.org/10.1080/01904167.2011.531362

Costa CR, Olivi P, Botta CMR, Espindola ELG (2008) A toxicidade em ambientes aquáticos: discussão e métodos de avaliação. Quim Nova 31:1820-1830. https://doi.org/10.1590/S0100$\underline{40422008000700038}$

Falagán C, Yusta I, Sánchez-España J, Johnson DB (2017) Biologically-induced precipitation of aluminium in synthetic acid mine water. Miner Eng 106:79-85. https://doi.org/10.1016/j.mineng.2016.09.028

Iatrou EI, Stasinakis AS, Aloupi M (2015) Cultivating duckweed Lemna minor in urine and treated domestic wastewater for simultaneous biomass production and removal of nutrients and antimicrobials. Ecol Eng 84:632-639. https://doi.org/10.1016/j.ecoleng.2015.09.071 
Water Qual. toxic Eff. water Const. waste water to duckweed (Lemna Minor. growth Inhib. test 1-23

359

360

361

362

363

364

365

366

367

368

369

370

Kaur G, Couperthwaite SJ, Hatton-Jones BW, Millar GJ (2018) Alternative neutralisation materials for acid mine drainage treatment. J Water Process Eng 22:46-58. https://doi.org/10.1016/j.jwpe.2018.01.004

Lalau CM, Mohedano R de A, Schmidt ÉC, et al (2015) Toxicological effects of copper oxide nanoparticles on the growth rate, photosynthetic pigment content, and cell morphology of the duckweed Landoltia punctata. Protoplasma 252:221-229. https://doi.org/10.1007/s00709-014$\underline{0671-7}$

Lalau CM, Simioni C, Vicentini DS, et al (2020) Toxicological effects of AgNPs on duckweed (Landoltia punctata). Sci Total Environ

710:136318. https://doi.org/10.1016/j.scitotenv.2019.136318

Lattuada RM, Menezes CTB, Pavei PT, et al (2009) Determination of metals by total reflection Xray fluorescence and evaluation of toxicity of a river impacted by coal mining in the south of Brazil. J Hazard Mater 163:531-537. https://doi.org/10.1016/j.jhazmat.2008.07.003

Lee BM, Kacew S, Kim HS, Lu FC (2018) Lu's Basic Toxicology: fundamentals, target organs, and risk assessment, 7th edn. CRC Press, Boca Raton

Mamelkina MA, Cotillas S, Lacasa E, et al (2017) Removal of sulfate from mining waters by electrocoagulation. Sep Purif Technol 182:87-93. https://doi.org/10.1016/j.seppur.2017.03.044

Martins M da C (2014) Avaliação genotóxica em hortaliças cultivadas em áreas de exploração de carvão: potencial mutagênico e riscos a saúde humana. p. Tese (Doutorado em Ciências da Saúde), Universidade do Extremo Sul Catarinense

Nagy A, Magyar T, Juhász C, Tamás J (2020) Phytoremediation of acid mine drainage using byproduct of lysine fermentation. Water Sci Technol 81:1507-1517. https://doi.org/10.2166/wst.2020.240

Nariyan E, Sillanpää M, Wolkersdorfer C (2017) Electrocoagulation treatment of mine water from the deepest working European metal mine - performance, isotherm and kinetic studies. Sep Purif Technol 177:363-373. https://doi.org/10.1016/j.seppur.2016.12.042

Netto E, Madeira RA, Silveira FZ, et al (2013) Evaluation of the toxic and genotoxic potential of acid mine drainage using physicochemical parameters and bioassays. Environ Toxicol Pharmacol 35:511-516. https://doi.org/10.1016/j.etap.2013.02.007

Núñez-Gómez D, Alves AAA, Lapolli FR, Lobo-Recio MÁ (2017) Aplication of the statistical experimental design to optimize mine-impacted water (MIW) remediation using shrimp-shell. Chemosphere 167:322-329. https://doi.org/10.1016/j.chemosphere.2016.09.094

Núñez-Gómez D, Rodrigues C, Lapolli FR, Lobo-Recio MÁ (2019) Adsorption of heavy metals from coal acid mine drainage by shrimp shell waste: Isotherm and continuous-flow studies. J Environ 
OECD (2006) Test ${ }^{\circ}$ 221: Lemna sp. Growth Inhibition Test. OECD Guidel. Test. Chem. Sect. 2 122

Pereira SPP, Jesus F, Aguiar S, et al (2018) Phytotoxicity of silver nanoparticles to Lemna minor: Surface coating and exposure period-related effects. Sci Total Environ 618:1389-1399. https://doi.org/10.1016/j.scitotenv.2017.09.275

Perreault F, Oukarroum A, Pirastru L, et al (2010) Evaluation of copper oxide nanoparticles toxicity using chlorophyll a fluorescence imaging in Lemna gibba. $J$ Bot 2010:1-9. https://doi.org/10.1155/2010/763142

Perreault F, Samadani M, Dewez D (2013) Effect of soluble copper released from copper oxide nanoparticles solubilisation on growth and photosynthetic processes of Lemna gibba L. Nanotoxicology 8:374-382. https://doi.org/10.3109/17435390.2013.789936

Radić S, Vujčić V, Cvetković Ž, et al (2014) The efficiency of combined CaO/electrochemical treatment in removal of acid mine drainage induced toxicity and genotoxicity. Sci Total Environ 466-467:84-89. https://doi.org/10.1016/j.scitotenv.2013.07.011

Rodrigues C, Follmann HVDM, Núñez-Gómez D, et al (2020a) Sulfate removal from mine-impacted water by electrocoagulation: statistical study, factorial design, and kinetics. Environ Sci Pollut Res 27:39572-39583. https://doi.org/10.1007/s11356-020-09758-1

Rodrigues C, Núñez-Gómez D, Follmann HVDM, et al (2020b) Biostimulation of sulfate-reducing bacteria and metallic ions removal from coal mine-impacted water (MIW) using shrimp shell as treatment agent. J Hazard Mater 398:122893. https://doi.org/10.1016/j.jhazmat.2020.122893

Rodrigues C, Núñez-Gómez D, Silveira DD, et al (2019) Chitin as a substrate for the biostimulation of sulfate-reducing bacteria in the treatment of mine-impacted water (MIW). J Hazard Mater 375:330-338. https://doi.org/10.1016/j.jhazmat.2019.02.086

Sánchez-Andrea I, Sanz JL, Bijmans MF, Stams AJ (2014) Sulfate reduction at low pH to remediate acid mine drainage. J Hazard Mater 269:98-109. https://doi.org/10.1016/j.jhazmat.2013.12.032

Shanker AK, Cervantes C, Loza-Tavera H, Avudainayagam S (2005) Chromium toxicity in plants. Environ Int 31:739-753. https://doi.org/10.1016/j.envint.2005.02.003

Soiltech (2021) Le manganèse, le petit nouveau parmi les éléments. https://soiltech.nl/fr/knowwhy/le-manganèse-le-petit-nouveau-parmi-les-éléments/. Accessed 19 Oct 2021

Stegemeier JP, Colman BP, Schwab F, et al (2017) Uptake and Distribution of Silver in the Aquatic Plant Landoltia punctata (Duckweed) Exposed to Silver and Silver Sulfide Nanoparticles. Environ Sci Technol 51:4936-4943. https://doi.org/10.1021/acs.est.6b06491

Tamás L, Huttová J, Mistrík I, et al (2006) Aluminium-induced drought and oxidative stress in barley roots. J Plant Physiol 163:781-784. https://doi.org/10.1016/j.jplph.2005.08.012 
Teles CC, Mohedano RA, Tonon G, et al (2017) Ecology of duckweed ponds used for nutrient recovery from wastewater. Water Sci Technol 75:2926-2934. https://doi.org/10.2166/wst.2017.172

Wang W (1990) Literature review on duckweed toxicity testing. Environ Res 52:7-22. https://doi.org/10.1016/S0013-9351(05)80147-1

Zezulka Š, Kummerová M, Babula P, Váňová L (2013) Lemna minor exposed to fluoranthene: Growth, biochemical, physiological and histochemical changes. Aquat Toxicol 140-141:3747. https://doi.org/10.1016/j.aquatox.2013.05.011

Ziegler P, Sree KS, Appenroth KJ (2016) Duckweeds for water remediation and toxicity testing. Toxicol Environ Chem 98:1127-1154. https://doi.org/10.1080/02772248.2015.1094701

Ziegler P, Sree KS, Appenroth KJ (2019) Duckweed biomarkers for identifying toxic water contaminants? Environ Sci Pollut Res 26:14797-14822. https://doi.org/10.1007/s11356-0183427-7

\section{Acknowledgements}

The funds for this research were provided by the National Council for Scientific and Technological Development (CNPq) and scholarship from the Coordination of Improvement of Higher Education Personnel (CAPES) - finance code 001.

\section{Credit Author Statement}

C. Rodrigues: conceptualization, methodology, investigation, reviewing, and editing.

C. M. Lalau: conceptualization, methodology, investigation, reviewing, and editing.

D. Núñez-Gómez: conceptualization and methodology.

R. C. Puerari: investigation, and reviewing.

H. V. D. M. Follmann: investigation, and reviewing.

B. V. Oscar: investigation, and reviewing.

F. R. Lapolli: project administration, and funding acquisition.

W. G. Matias: conceptualization, writing, and reviewing.

M. Á. Lobo-Recio: conceptualization, supervision, writing, and reviewing. 